\title{
Effectiveness of Bibliotherapy on the Level of Stress among Old Age in Selected Old Age Home, Chennai
}

\author{
V. Hemavathy', S. Rengila ${ }^{2}$ \\ Principal, Sree Balaji College of Nursing, Bharat University, Chennai, India \\ II nd Year M.Sc Nursing, Sree Balaji College of Nursing, Bharat University, Chennai, India
}

\begin{abstract}
Background of the Study: Ageing is a natural process as there is no concrete work schedule to follow, and they start feeling unwanted. When all the young members of the family are busy in their discourses of life, old people lack the love and attention they need. All these factors contribute in stressing in old age. Objectives: To assess the pretest and posttest level of stress among old age in the experimental and control group. Evaluate the effectiveness of bibliotherapy on stress among old age in experimental and control group associate the level of stress among old age with selected demographic variables in experimental group. Hypothesis: There will be a significant difference between the post test score of stress in experimental and control group among old age. There will be a significant association between the post level of stress among old age and their selected demographic variables in experimental and control group among old age. Methodology: Nonequivalent control group pre-test and post-test design was used for this study. Purposive sampling technique was used for the study. Final Result And Conclusion: In the pretest the level of stress among selected 30 samples in experimental group 2(6.7\%) Of them had average level of stress and 20(66.6\%) of them had slightly higher level of stress and 8(26.7\%) had much higher level of stress.In the post test level of stress among selected 30 samples in experimental group 4(13.3\%) had very lower level of stress $17(56.7 \%)$ had slightly lower level of stress $6(20 \%)$ had average level of stress $2(6.7 \%)$ had slightly higher level of stress and 1(3.3\%)had much higher level of stress. The effectiveness of Bibliotherapy on level of stress among elderly using paired " $t$ " test shows 24.1 significant at the level of $P<0.001$ which implying that there was significant decrease in the level of stress among old age people in the post test
\end{abstract}

Keywords: effectiveness, bibliotherapy, old age, old age home

\section{Introduction}

Growing old in a society that has been obsessed with youth may have a critical impact on the mental health of many people. By Chris Woolston, M.S. - At any age, stress is a part of life. Young and old alike have to face difficult situations and overcome obstacles The National Health Interview Survey (2009) shows that 75 percent of old age population experiences at least some stress, half of those experience moderate or high levels of stress during their life time.. There are a lot of therapies and medications used to reduce stress in old age. Bibliotherapy is one among them..."Bibliotherapy has been defined as " the therapeutic use of books in the treatment of illnesses or personal problems" (Stanley, 2002) good literature is a true reflection of life, and memorable characters are often relatable and critical to believability in stories, especially when they are supposed to be reflections of real people. This is why words, stories and books are so powerful, and potentially so therapeutic in the medical setting.

\section{Objectives}

- To assess the pretest and posttest level of stress among old age in the experimental and control group.

- To evaluate the effectiveness of bibliotherapy on stress among old age in experimental and control group.

- To associate the level of stress among old age with selected demographic variables in experimental group.

\section{Hypothesis}

$\mathrm{H}_{1}$ There will be a significant difference between the post test score of stress in experimental and control group among old age.

$\mathrm{H}_{2}$ There will be a significant association between the post level of stress among old age and their selected demographic variables in experimental and control group among old age

\section{Methodology}

Quasi experimental Nonequivalent control group pre-test and post-test design was selected for this study in Sree Sathya Narayanan old age home Chennai. The study population will comprise of old age people in the age group of (50-70) years. Total sample size 60 both male and female old age people are selected for the study by Purposive sampling technique. The questionnaire has 2 parts consisting of Demographic variables these are age, sex, marital status, religion, domicile, duration of stay in old age home, performance of activity of daily living, nature of admission in old age home, education in the second part of questionnaire Cohens Perceived stress scale consisting of 14 items` was used. Interpretation of score was done as follow.

Table 1

\begin{tabular}{|c|c|}
\hline Category & Score \\
\hline Much lower than average & $0-7$ \\
\hline Slightly lower than average & 11 -Aug \\
\hline Average & $15-$ Dec \\
\hline Slightly higher than average & $16-20$ \\
\hline Much higher than average & 21 and over \\
\hline
\end{tabular}




\section{International Journal of Science and Research (IJSR) ISSN (Online): 2319-7064 \\ Index Copernicus Value (2013): 6.14 | Impact Factor (2014): 5.611}

\section{Result}

Table -2: Pre test level of stress among old age people

\begin{tabular}{|c|c|c|c|c|}
\hline \multirow{2}{*}{ Pretest level of stress } & \multicolumn{2}{|c|}{$\begin{array}{l}\text { Experimental } \\
\text { Group }\end{array}$} & \multicolumn{2}{|c|}{ Control Group } \\
\hline & No & $\begin{array}{c}\text { Percentage } \\
(\%)\end{array}$ & No & $\begin{array}{c}\text { Percentage } \\
(\%)\end{array}$ \\
\hline Much lower than average & - & - & - & - \\
\hline $\begin{array}{c}\begin{array}{c}\text { Slightly lower than } \\
\text { average }\end{array} \\
\end{array}$ & - & - & - & - \\
\hline Average & 2 & 6.7 & 2 & 6.7 \\
\hline $\begin{array}{c}\text { Slightly higher than } \\
\text { average }\end{array}$ & 20 & 66.7 & 21 & 70 \\
\hline Much higher than average & 8 & 26.7 & 7 & 23.3 \\
\hline Total & 30 & 100 & 30 & 100 \\
\hline
\end{tabular}

Table 2 Reveals the pre test scores of both experimental \& control group. Among the experimental group (6.7\%) experienced average level of stress (66.7\%) experienced slightly higher level of stress and (26.7\%) experienced much higher level of stress. In control group majority of the samples experienced slightly higher level of stress (70\%) 2 out of 30 (6.7\%) experienced average level and 7 out of 30 experienced much higher level of stress.

Table 3: Post test level of stress among old age people

\begin{tabular}{|c|c|c|c|c|}
\hline \multirow{2}{*}{ Posttest level of stress } & \multicolumn{2}{|c|}{$\begin{array}{c}\text { Experimental } \\
\text { Group }\end{array}$} & \multicolumn{2}{c|}{$\begin{array}{c}\text { Control } \\
\text { Group }\end{array}$} \\
\cline { 2 - 5 } & No & Percentage (\%) & No & Percentage (\%) \\
\hline Much lower than average & 4 & 13.3 & - & - \\
\hline Slightly lower than average & 17 & 56.7 & - & - \\
\hline Average & 6 & 20 & 2 & 6.7 \\
\hline Slightly higher than average & 2 & 6.7 & 23 & 76.7 \\
\hline Much higher than average & 1 & 3.3 & 5 & 16.6 \\
\hline Total & 30 & 100 & 30 & 100 \\
\hline
\end{tabular}

In the post test majority of the samples experienced 4 out of 30 samples experienced much slightly lower level of stress (56.7\%), 6 out of 30 experienced average level of stress 2 out of 30 experienced slightly higher and 1 out of 30experienced much higher level of stress and in control group 2 out of 30 experienced average level of stress, 23 out of 30 experienced much higher level of stress and 5 out of 30 experienced much higher level of stress.

Table 4: Comparison of pre test and post test Level of stress among old age people

\begin{tabular}{|c|c|c|c|c|c|c|c|c|}
\hline \multirow{3}{*}{ Stress level } & \multicolumn{3}{|c|}{$\begin{array}{c}\text { Experimental } \\
\text { group } n=30\end{array}$} & \multicolumn{4}{c|}{$\begin{array}{c}\text { Control } \\
\text { group } n=30\end{array}$} \\
\cline { 2 - 9 } & Pre test & Post test & Pre test & Post test \\
\hline & F & $\%$ & F & $\%$ & F & $\%$ & f & $\%$ \\
\hline Much lower than average & - & - & 4 & 13.3 & - & - & - & - \\
\hline Slightly lower than average & - & - & 17 & 56.7 & - & - & - & - \\
\hline Average & 2 & 6.7 & 6 & 20 & 2 & 6.7 & 2 & 6.7 \\
\hline Slightly higher than average & 20 & 66.7 & 2 & 6.7 & 21 & 70 & 23 & 76.7 \\
\hline Much higher than average & 8 & 26.7 & 1 & 3.3 & 7 & 23.3 & 5 & 16.6 \\
\hline
\end{tabular}

Table 4 depicts the pre test\& post test scores of both experimental \& control group. Among the experimental group (6.7\%) experienced average level of stress (66.7\%) experienced slightly higher level of stress and (26.7\%) experienced much higher level of stress. But in the post test majority of the samples experienced slightly lower level of stress (56.7\%), 6 out of 30 experienced average level of stress 2 out of 30 experienced slightly higher and 1 out of 30experienced much higher level of stress. In control group in the pre test, majority of the samples experienced slightly higher level of stress (70\%) 2 out of 30 (6.7\%) experienced average level and 7 out of 30 experienced much higher level of stress. the effectiveness of Bibliotherapy among old age people the stress mean score in experimental group was 19.3 in the pre -test, SD was 3.6 and mean post -test score was 11 and SD was 3.4, so the mean difference was 8.3 with the paired t- test value is 24.1 and there is significant effectiveness at $\mathrm{P}$ value $<0.001$.

\section{Major findings of the study}

Reveals that in experimental group majority (10\%) of the samples were in the age group of 50-55 years in experimental group (36.6\%) of samples belonged to the age group of 56-60 years,(30\%) of samples belong to age group of 61-65years, and (23.4\%) of samples belong to age group of $66-70$ years. Regarding the sex status (33.3\%) of males and $(66.7 \%)$ of females belong to experimental group. In both the groups the patients was Hindu by religion (100\%) in experimental group and control group. Regarding marital status about $(53.4 \%)$ were in the widow criteria in experimental group and (53\%) were in the widow criteria in control group. In both the groups most of the patients were hailing from urban (60\%) in both experimental group and control group. Rural (40\%) in both experimental group and control group. Regarding support system about (46.7\%) were in relatives support in experimental group and control group (56.7\%). Regarding the duration of stay in the old age home 3-4 years (30\%) experimental group and control group (46.6\%)above 4years. Regarding performance of activities of daily living (97\%) independent experimental and control group (3\%) partially independent in both experimental and control group. Recording the nature of admission to the old age home (70\%) was in voluntary admission in experimental group (30\%) forced by children's. (73.3\%) was in voluntary admission and (26.7\%) were forced by children's in control group. Regarding educational status were secondary (46.7\%) experimental and control group (50\%).

The pre test stress level among the experimental group (6.7\%) experienced average level of stress (66.7\%) experienced slightly higher level of stress and (26.7\%) experienced much higher level of stress. But in the post test majority of the samples experienced slightly lower level of stress (56.7\%), 6 out of 30 experienced average level of stress 2 out of 30 experienced slightly higher and 1 out of 30experienced much higher level of stress. In control group in the pre test, majority of the samples experienced slightly higher level of stress (70\%) 2 out of 30 (6.7\%) experienced average level and 7 out of 30 experienced much higher level of stress

\section{Conclusion}

The study reveals that there was significant decrease in the level of stress among old age people in the post test. The effectiveness of Bibliotherapy among old age people using paired "t" test shows 24.1 significant at the level of $\mathrm{P}$ 
$<0.001$ in experimental group and paired " $t$ " test showed 6 in control group significant at the level of $\mathrm{P}<0.001$.

\section{References}

[1] Townsend CM. Psychiatric mental health nursing Concepts of care. $4^{\text {th }}$ edition. Philadelphia: F.A Davis Company ;2006

[2] Doris Smith Suddarth. The Lippincott Manual of Nursing Practice. $5^{\text {th }}$ ed. New Delhi: JB Company; 1999.

[3] Levin, Lydia. Bibliotherapy: A general discussion relating to the reader, the librarian, and its therapeutic potential. Libri Natales 1987 April; 12 (7)

[4] Seljamo S. Self-help intervention in depression and stress: A Prospective follow up Study: 2004 July; 101(7)

[5] Fortinash, et al. Psychiatric Mental Health Nursing. $1^{\text {st }}$ ed. Missouri: Mosby Publications; 1996.

[6] Aldwin C.inter disciplinarian, stress and coping in old age. Boise 2005. April 13 4:7

[7] Kaplan \& Sadock. Comprehensive Text book of Psychiatry. $7^{\text {th }}$ ed. Philadelphia: Lippincott Publisher; 2000.

[8] Lazarus \& Stuart. Principles and Practice of Psychiatric Nursing. $6^{\text {th }}$ ed. Philadelphia: Mosby Company;1990

[9] Grainne Mc Kenna. "Bibliotherapy: A review of its efficacy in clinical settings". 2008 August

[10] Ahuja Neeraj, Vyas J N. Text book of postgraduate psychiatry. $2^{\text {nd }}$ ed. New Delhi: Jaypee Brothers Medical Publishers (P) LTD; 2003.

\section{Net References}

[11] http/www.intelihealth.com

[12] http/www.learnwell.og/relax.htm

[13] http/www.pubmed.com

[14] http://www heartquotes.com

[15] http://www.eric.ed.gov 